International Journal of Engineering \& Technology, $7(4.7)(2018) 85-87$
International Journal of Engineering \& Technology
SPC
Website: $w w w . s c i e n c e p u b c o . c o m / i n d e x . p h p / I J E T$
Research paper

\title{
Innovative Technologies of Teaching Business French
}

\author{
Elena K. Kuzmina1, Gulnara I. Nazarova1, Liliya R. Nizamieva1, Cécile Leblanc2 \\ 1Kazan Federal University \\ 2Université Sorbonne Nouvelle-Paris 3 \\ *Corresponding author E-mail: lenysinka@yandex.ru
}

\begin{abstract}
The article deals with the peculiarities of modern technologies in teaching professional French, taking into account the requirements of international examinations, specific language-learning needs of students and level of their language proficiency. Pedagogical technologies are demonstrated by the example of teaching business French in the sphere of tourism, hotel business, as well as the guideinterpreters training. The educational courses are aimed at the development of basic speaking skills and skills necessary for business communication in French. The developed pedagogical technology is based on French for specific purposes (FOS) methodology and cognitive-practical activity methods that allow to develop trainees' communicative competence and their cognitive independence effectively. One of the conditions for successful development of communicative competence in the field of business communication in a foreign language is to ensure that students do the necessary number of training exercises, in particular, connected with the use of business vocabulary, as well as with speaking exercises aimed at solving communication problems in real life situations of business communication. Similarity to the real life business environment is achieved through the use of information technologies and simulation games, which ultimately enhances the individual's ability to interact with others and adapt in the social and professional spheres of life. Successful completion of the end-of-course assessment is indicative of the fact that the students have reached high business communication competency.
\end{abstract}

Keywords: professional French, international examinations, pedagogical technologies, French for specific purposes, methods of cognitive-practical activity.

\section{Introduction}

At the current stage of social development the process of international integration contributes to the expansion of economic ties between countries, the emergence of various types of cooperation in business, the growth of population mobility in the sphere of personal and business contacts, which requires a certain level of linguistic competence, both at the day-to-day and professional levels of communication. Cross-cultural communication has an impact on various spheres of communication. Effective communication, in its turn, is impossible without certain language skills. The demand for qualified specialists who know foreign languages at a high level and are able to communicate fluently in the business sphere with their foreign colleagues, clients and partners is increasing. Good basic foreign language skills are often not enough for business communication, and specialists in various fields need this kind of communication to be effective.

Higher education curricula in the sphere of foreign languages, as a rule, include a business communication course. Thus, the course "Business French" is aimed, in particular, at teaching students how to conduct business correspondence, participate in negotiations and interviews, talk business, etc. However, these skills and general knowledge in business communication are not enough if there is a necessity for regular communication in a foreign language in a certain professional field. In this regard, specialized professional language courses are offered for people who want to master business French.

\section{Methods}

The International Linguistic Center of the Kazan Federal University trains students and conducts a final assessment of their business French skills. The center is engaged in the development of educational programs meeting the European standard requirements and the preparation of educational materials for the organization of language courses. The priority area in the field of the French language is business French for tourism, hotel business, as well as the training of guides and interpreters. These courses are designed for people working in tourism, hotel and restaurant business and for those who want to work in the field. The courses allow students to learn basic vocabulary and develop basic grammar and speaking skills that are necessary for communication in French in the sphere tourism and hotel business. Successful completion of the course allows students to get a certificate of the International Linguistic Center of Kazan Federal University, which verifies the communicative competency in this business field.

The technology of teaching business French is quite specific. One of the bases in its development was French for specific purposes (FOS) methodology, aimed at teaching French as a foreign language for its use in niche areas of communication [Carette et al., 2012; Mangiante, 2004; Calmy, 2004].The methodology is studied and developed by a special committee, with support from the French Language Center of the Paris Chamber of Commerce and Industry. 
When using the FOS methodology, it is necessary, first of all, to determine the specific traits of the study group to which the professional French will be taught, and only then to develop teaching technologies [Mourlhon-Dallies, 2006; Parpette, Mangiante, 2012] According to the FOS concept, the teacher is invited to follow these five steps [Mangiante, 2015]:

Identify students' specific language-learning needs.

Analyze these needs and choose teaching methods accordingly.

3. Collect data on the peculiarities of French usage in the area of communication students need to work on (special features of business communication situations, linguistic peculiarities, for example, professional terminology). The teacher can use various teaching aids, reflecting linguistic peculiarities of a certain professional field.

4. Develop training technologies and select appropriate didactic materials.

\section{Evaluate learning outcomes.}

It must be noted that the necessity to choose teaching techniques and methods according to certain language-learning and professional needs of students is proved in Russian methodology as well. For example, L.V. Shcherba believed that "for the development of language teaching methodology it is important to analyze what practical challenges we can face when using those languages" [Shcherba, 2003]. Modern Russian researchers are also developing this idea. They believe that in order to choose the most appropriate and effective educational technologies, one should start from the specific tasks the students deal with [Yarmakeev et al., 2017]. The usage of FOS methodology entails the necessity of students' language-learning needs analysis in order to find out what exactly they need to know for various business communication situations, and to include in the study content speech patterns and the information about extra-linguistic peculiarities widely spread in those situations [Richterich, 2000].

\section{Results and Discussion}

Having adapted the FOS methodology to courses ofbusiness French in the sphere of tourism and hotel business, in the process of training technologies development we seek to:

1. assess language level of each group of students;

2. analyze the requirements that applicants need to meet in the exam;

3. determine the necessary number of course hours and the optimal course intensity;

4. determine the level of speaking competency that the students should reach;

5. develop training technologies which ultimately determine the selection of necessary didactic material and teaching aids.

We believe that in order to carry out professional activities in the aforementioned field, the business French proficiency level should not be lower than Level B1 of the Common European Framework of Reference for Languages, therefore, students should initially have Level A2 or higher. Business French course includes about 240-270 hours of preliminary General French learning and 90-120 hours of business French connected with a specialization. It is optimal to form groups of students with the same French level, but this is not always possible, therefore, the teacher should use individual approach to each student and the tasks should be selected depending onthe students'French proficiency level.

In the process of taking the courses, the applicant must acquire the following competencies:

the knowledge of professional terminology in the field of tourism, restaurant and hotel business; typical communicative situations related to professional activities; the fundamentals of the tourist business organization, necessary for carrying out professional activities in French; requirements for drawing up professional documentation and its compilation (summaries, announcements, letters, etc.) in French.

the ability to understand the main content of clearly pronounced statements on various professional topics related to the sphere of tourism; to understand written texts based on the linguistic material of professional communication in the field of tourism; to express their thoughts on professional issues coherently, briefly substantiate and explain their views and intentions; to communicate orally and in writing in typical business situations in the sphere of tourism.

the skills of using professional vocabulary in oral and written communication in typical situations occurring in the field of tourism, restaurant and hotel business; French speaking skills, necessary to solve professional tasks in the aforementioned business areas; the skills of planning and developing a tourist product and its promotion in the tourist business market.

The main goal of the end-of-course assessment in business French in the sphere of tourism and hotel industry is the same as in all major international exams in French. It is to determine the communicative competency of the applicant.

This competency is determined by the level of development of four types of language skills: speaking, reading, listening and writing, so the applicants' training includes the formation of those skills up to a certain level.

Professional French training technologies are based on the concept of cognitive-practical activity methods developed by the Kazan didactic school [Nizamieva et al., 2016]. The application of these educational technologies allows to effectively develop the communicative competency of the students, as well as their cognitive independence.

One of prerequisites for the successful cognitive and practical activity methods functioning is the wide use of authentic written, audio and video materials accompanying real life situations of business communication in tourism, restaurant and hotel business [Subich et al., 2016; Varlamova et al., 2016]. These materials should be carefully analyzed and studied as a speech pattern. They are the base for role-play situations and simulation games development. For example, in the framework of guide-interpreters' training one of the assignments is to compile and conduct both real and virtual tours of the capital of the Republic of Tatarstan, Kazan, in a foreign language. The preliminary itinerary includes details about the time and place of departure, travel details, suitable means of transport, a blow-by-blow account of the guided tour programme. The rest of the students act as the potential clients and prepare various questions that the guide can get in a real life situation of professional communication.

Let us consider the specifics of the developed technologies using the example of teaching how to discourse in the sphere of tourism, restaurant and hotel business. The structure of mastering any kind of oral discourse includes an indicative basis for action. In accordance with the conditions under which cognitive-practical activity methods function, at the first stage students are offered standard samples of the studied oral speech type. They can include telephone bookings, conversation with a customer in a travel agency, description of architectural and natural sites, a restaurant advertisement, a restaurant menu, discussion of a tourist operator's cata$\log$, a map or an itinerary, an advertisement of a tourist product, various types of professional communication (an inquiry about vacant rooms in a hotel and accommodation conditions, booking confirmation, complaints) and many other things. Students are asked to analyze the sample in regard to its structure, content and linguistic peculiarities.

The next stage is the development of speaking skills. On this stage,there should be enough of training and proper speaking exercises. Students do the necessary vocabulary and grammar exercises, as well as exercises aimed at modification of a speech pattern. The focus should be on the use of professional terminology and syntactic constructions typical for this or that type of discourse. It should be noted that studying basic French grammar is 
not the goal when mastering business language, but grammar skills are, nevertheless, being developed with the help of working on speech patterns typical for this professional sphere.

\section{Summary}

Doing enough of training and speaking exercises brings students to the next level in mastering oral discourse, when the acquired skills improve further in the process of writing original texts in accordance with the given learning situations. At first, the texts are based on a sample or written with the teacher's help, and only after that the students start writing on their own.

Consistent application of the described technologies in the process of studying various types of oral and written discourse teaches students to work with standard patterns and leads to the development of their cognitive independence.

The described technique is supplemented by information technologies that help to make the educational process more efficient, improve the communicative competency of students in a foreign language and develop their cognitive independence [Dejean et al., 2011]. The application of these technologies creates a virtual linguistic and cultural space, thereby contributing to the development of speaking, sociocultural and compensatory competencies [Harvey, 2012; Rakhimovaet al., 2017]. The actual websites of tour operators are used in class. They are the base for the analysis of tourist products, professional terminology, comments and questions of clients, what eventually helps to get a better understanding of the language usage in the aforementioned business sphere. The wide use of simulation games adds to the development of students' communicative competency, their creative potential and creative abilities.

\section{Conclusions}

As a result of business French training students demonstrate a high level of their communicative competency, which is sufficient for work with French-speaking clients and colleagues in the sphere of tourism, hotel and restaurant business. The successful completion of the language course final assessment in the International Linguistic Center of Kazan Federal University is a reliable and objective indicator of one's foreign language proficiency level and the efficiency of educational technologies used in the learning process

\section{Acknowledgement}

The work is carried out according to the Russian Government Program of Competitive Growth of Kazan Federal University.

\section{References}

[1] 1. Carette, E., Carton, F., Vlad, M. (2012). Diversités culturelles et enseignement du français dans le monde. Paris: PUG. 263 p.

[2] 2.Mangiante, J. (2004). Le Français sur objectif spécifique: de l'analyse des besoins à l'élaboration d'un cours. Paris: Hachette. $161 \mathrm{p}$.

[3] 3.Calmy, A.-M. (2004). Le français du tourisme. Paris: Hachette livre. $160 \mathrm{p}$

[4] 4.Mourlhon-Dallies, F. (2006). Apprentissage du français en contexte professionnel: état de la recherche // Apprendre le français dans un contexte professionnel. Actes de rencontres de la Délégation Générale de la Langue Française. Paris. P. 28-33.

[5] 5.Parpette, C.,Mangiante, J. (2012). Le français sur objectif universitaire.Paris: PUG. 246 p.

[6] 6.Mangiante, J. (2015). La grammaire en Français sur Objectif Spécifique (FOS) : une place, un rôle et une démarche différents? // Le Français dans le Monde, Recherches et applications. № 57. Paris: Clé International. P. 96-107.

[7] 7.Shcherba, L.V. (2003).Teaching languages in a secondary school: general issues of methodology. Moscow: Academia. $160 \mathrm{c}$.
[8] 8.Yarmakeev, I.E., Pimenova, T.S., Abdrafikova, A.R. (2017). English for Specific Academic Purposes as a Need and Tool of Communicative Competency Formation // The European Proceedings of Social \& Behavioural Sciences. (August, 31). Vol. XXIX. P. 871-878.

[9] 9.Richterich, R. (2000). Besoins langagiers et objectifs d'apprentissage. Paris: Hachette. 175 p.

[10] Jana Arturovna KLAAS, Thomas Arturovich KLAAS Econometric Model of Early Diagnosis of a Credit Institution Bankruptcy Risk, Astra Salvensis, Supplement No. 2/2017, p. 107.

[11] Subich, V.G., Shangaraeva, L.F., Zakirova, L.R. (2016). Improvement of the English language communicative competencies by means of authentic texts // Journal of Language and Literature. 7(2). P. 257-261.

[12] 12.Dejean, C., Mangenot, F., Soubrié, T. (2011). Apprentissages formels et informels, autonomie et guidage // Actes du colloque EPAL 2011, Université Stendhal - Grenoble 3, 24-26 juin 2011. P. 9-15.

[13] 1 Shatilova L.M., Borisova V.V., Kasatkina O.A. (2018). Representation of the linguistic and cultural concept "lie" in the French and Russian language picture of the world, 34(85), Pp. 194-212.

[14] 2 Bakhyt S., Kalimbetov B., Khabibullayev Z. (2018). Possibilities of Mathematical Problems in Logical Thinking, Development of Secondary Education Pupils, 34(85), P.p. 321-338

[15] 15.Rakhimova, A.E., Yashina, M.E., Mukhamadiarova, A.F., Sharipova, A.V. (2017). The Development of Sociocultural Competence with the Help of Computer Technology // Interchange. 48(1). P. 55-70. 